\title{
Investigating the Integration of Student Learning Resources in Preparation for the NCLEX-RN: Phase One of a Canadian Two-Phase Multi-Site Study
}

Shelley L. Cobbett

Dalhousie University, shelley.cobbett@dal.ca

Willena I. Nemeth

Cape Breton University, willena_nemeth@cbu.ca

JoAnne MacDonald

St. Francis Xavier University, jomacdon@stfx.ca

Follow this and additional works at: https://qane-afi.casn.ca/journal

Part of the Other Education Commons, and the Other Nursing Commons

\section{Recommended Citation}

Cobbett, Shelley L.; Nemeth, Willena I.; and MacDonald, JoAnne (2016) "Investigating the Integration of Student Learning Resources in Preparation for the NCLEX-RN: Phase One of a Canadian Two-Phase Multi-Site Study," Quality Advancement in Nursing Education - Avancées en formation infirmière: Vol. 2: Iss. 2, Article 7.

DOI: https://doi.org/10.17483/2368-6669.1079

This Article is brought to you for free and open access by Quality Advancement in Nursing Education - Avancées en formation infirmière. It has been accepted for inclusion in Quality Advancement in Nursing Education - Avancées en formation infirmière by an authorized editor of Quality Advancement in Nursing Education - Avancées en formation infirmière. 


\section{Investigating the Integration of Student Learning Resources in Preparation for the NCLEX-RN: Phase One of a Canadian Two-Phase Multi-Site Study}

\section{Cover Page Footnote}

A special thank you to all of the new nursing graduates that participated in this study for without your support, this study would not have taken place. Appreciation is extended to Elsevier/HESITM for awarding the Team with an Educational Research Grant for this research study. Conflict of interest was mitigated with a clear statement in the agreement for acceptance of funding that the results would be disseminated and published, regardless of the findings. Elsevier/HESITM was not involved in any phase of the research study and does not have access to the data base, either at the school or aggregate level. The team would like to extend their sincere gratitude to Dr. Amy Grant, for her statistical expertise and guidance with data analysis and interpretation. Nous aimerions remercier tout particulièrement tous les nouveaux diplômés en sciences infirmières qui ont participé à cette étude, et sans qui l'étude n'aurait pas pu être réalisée.. Notre reconnaissance s'étend également à Elsevier/HESIMD pour avoir accordé à l'équipe une subvention de recherche en éducation pour cette étude. Le conflit d'intérêts a été atténué grâce à une déclaration claire inscrite dans l'entente d'acceptation du financement indiquant que les résultats de l'étude seraient diffusés et publiés quelles que soient les résultats. Elsevier/HESIMD n'a participé à aucune phase de l'étude de recherche et n'a pas accès à la base de données, ni au niveau des écoles ni au niveau cumulatif. L'équipe aimerait également exprimer sa sincère reconnaissance à Dre Amy Grant pour son expertise et ses conseils en statistique lors de l'analyse et de l'interprétation des données.

\section{Erratum}

Corrected Author credential display and honorific. Added indent to the first paragraph of Methods section. 


\section{Introduction}

Student success on the national licensure exam for entry to practice as a registered nurse is a national issue and an outcome that all nursing schools desire. In December 2011, the Canadian Council of Registered Nurse Regulators (CCRNR) and several provincial nursing regulatory agencies announced that applicants requesting registration as a registered nurse (RN) within some Canadian provinces would be required to successfully complete the computeradaptive NCLEX-RN exam, administered by the American organization, the National Council of State Boards of Nursing (NCSBN). In response, university schools of nursing in the eastern province conducted an environmental scan to assess available NCLEX-RN learning resources to help prepare students for optimal success. Based on our assessment, representatives from the three universities that offer nursing degrees in an eastern-Canadian province approached Health Education Systems Incorporated (HESI), and negotiated a provincial package of learning resources. HESI has been providing nursing schools in other countries with tools to prepare and measure student progress and subsequent NCLEX-RN predictive success since 1999. The Phase One results of a two-phased, multi-site, ex post facto study investigating HESI NCLEX-RN student preparatory learning resources within the Canadian context are provided in this article.

\section{Background}

There are over 30 published peer-reviewed articles and several theses and dissertations, which span a decade of research, that support the validity and reliability of the HESI RN Exit Exams. More than 50 research studies have been published describing the use of HESI testing within nursing, health care settings, and other health care professions (Nibert \& Morrison, 2013). We reviewed over 75 journal articles and 42 theses/dissertations related to the use of HESI learning resources and NCLEX-RN preparation. Educators have reported HESI exams to be successful measures for benchmarking program outcomes, measuring student achievement, and guiding remediation prior to licensure candidacy (Barton, Willson, Langford, \& Schreiner, 2014).

HESI exams are standardized, nationally normed, and statistically analyzed at the item level. They cover the main concepts and areas of practice correlated to those found on the NCLEX-RN exam. Test item formats include multiple-choice, multiple-response, fill-in-theblank, hot spot, ranking, chart/exhibit, and multimedia: audio and video. The exams are built to mirror the most recent NCLEX-RN exam blueprint outlining the content areas that will be tested and is prepared by the NCSBN. An analysis of 11 validity studies, with over 63,000 students at more than 150 academic institutions, cumulatively indicated that the HESI exams have $97.4 \%$ accuracy in predicting success on the NCLEX-RN (Zweighaft, 2014).

Providing valid and reliable test items for each of the exams is important to ensure that the exams are reflective of high-quality critical thinking test items. Students taking more versions of the same exam receive reliable equivalent test versions with items that they have not previously seen. Reliability is determined by conducting item analyses on each exam and statistically calculating reliability using internal consistency measures. End-of-course and program testing and Exit Exams $\left(\mathrm{E}^{2}\right)$ range in the highest categories for estimated reliability coefficients using Kuder-Richardson Formula 20 (KR-20), ranging from 0.84 to 0.94 (Barton et al., 2014). Table 1 includes exam specific data from ten validity studies. Predictive accuracy is defined as the accuracy with which the HESI exams predict NCLEX-RN success. For clarity, Table 2 contains information related to the HESI examinations that were used within this study. 
Table 1: Predictive Accuracy of NCLEX-RN Success with Registered Nurse (RN) HESI Exit Exam Validity Studies

\begin{tabular}{|l|l|l|l|}
\hline \multicolumn{1}{|c|}{ Study } & Sampling Method & \multicolumn{1}{|c|}{$\begin{array}{c}\text { Participants } \\
\text { (N) }\end{array}$} & $\begin{array}{l}\text { Predictive } \\
\text { Accuracy }\end{array}$ \\
\hline Lauchner, Newman, \& Britt (1999) & Convenience & 2,555 & 97.3 \\
\hline Newman, Britt, \& Lauchner (2000) & Convenience & 3,296 & 96.5 \\
\hline Nibert \& Young (2001) & Convenience & 5,588 & 97.6 \\
\hline Nibert, Young, \& Adamson (2002) & Convenience & 5,903 & 98.3 \\
\hline Lewis (2005) & Convenience & 9,695 & 97.8 \\
\hline Adamson \& Britt (2009) & Convenience & 10,147 & 96.4 \\
\hline Young \& Willson (2012) & Stratified Random & 4,383 & 99.2 \\
\hline Langford \& Young (2013) & Stratified Random & 4,134 & 98.3 \\
\hline Zweighaft (2013) & Stratified Random & 3,790 & 96.6 \\
\hline $\begin{array}{l}\text { Barton, Willson, Langford, \& Schreiner } \\
\text { (2014) }\end{array}$ & Stratified Random & 5,438 & 98.3 \\
\hline Zweighaft (2014) & & & \\
\hline
\end{tabular}

Table 2: HESI Products

\begin{tabular}{|l|l|}
\hline \multicolumn{1}{|c|}{ HESI Product } & \multicolumn{1}{c|}{ Description } \\
\hline Computer Adaptive Test (CAT) & $\begin{array}{c}\text { - Simulates NCLEX-RN testing environment } \\
\text { - Provides a tailored item selection based on the student's } \\
\text { performance on the previous items }\end{array}$ \\
& $\begin{array}{l}\text { - } 85 \text { to } 155 \text { questions based on student performance as it is } \\
\text { adaptive }\end{array}$ \\
\hline $\begin{array}{l}\text { RN Exit Exam }\left(\mathrm{E}^{2}\right) \text { (Versions 1 } \\
\text { and 2) }\end{array}$ & $\begin{array}{l}\bullet \text { Contains 150 multiple format questions on each version } \\
\text { Designed to test a student's understanding of nursing } \\
\text { content based on the NCLEX-RN test plan }\end{array}$ \\
& $\begin{array}{l}\text { Is a computer-based exam, but it is not a computer- } \\
\text { adaptive assessment }\end{array}$ \\
\hline
\end{tabular}

Research suggests that the use of comprehensive exit assessments is a valuable formative strategy in nursing education (Sugg, 2015). Although the use of the term exit exam would suggest a summative evaluation, it is used within our nursing programs as a formative evaluation prior to writing the NCLEX-RN exam for national licensure.

A remediation report is generated from the students' results of their individual HESI RN Exit Exam. Each packet is targeted specifically to each student's unique knowledge strengths and 
deficits, as identified on their Individual Scoring Report. Students receive feedback about subjects answered incorrectly and detailed analyses to help them improve performance on subsequent exams. The remediation report is delivered through an online portal in a timely manner (within 24 to 48 hours) after the exam is administered and closed. Remediation is provided in multiple formats to address varied learning styles, is available to the student indefinitely, and can be used after they graduate. HESI RN Exit Exam Version 2 scores have been found to be higher in nursing schools that require, rather than encourage, remediation based upon the individualized remediation report that is provided to each student after the exam writing (Lauer \& Yoho, 2013).

Findings from Hyland's (2012) integrative literature review, conducted to investigate strategies that promote NCLEX-RN success, indicated that pass rates were improved among nursing programs that implemented standardized testing. Similar findings were reported by Homard (2013), who conducted an ex post facto correlational study to compare HESI RN Exit Exam scores and NCLEX-RN pass rates of nursing students. Students who participated in four semesters of standardized testing obtained higher exit exam scores and NCLEX-RN pass rates compared to those students who did not participate in standardized testing (Homard, 2013).

Little is known about effective guidelines for NCLEX-RN examination preparation, remediation, testing, and re-testing within the Canadian context. As such, the first phase of this study begins to fill this gap. The knowledge from this research will help inform Canadian nursing schools about best practices for preparing nursing students for optimal success when writing their national licensure examinations. This marks the beginning of a national evidenceinformed knowledge base that will inform nursing curricula and advance the scholarship of learning and teaching.

\section{Methods}

An ex post facto design was used for a two-phase multi-site correlational research study. Phase One, the focus of this article, was to determine if there was a relationship between student HESI RN Exit Exam and CAT exam scores, student grade point average (GPA) and the time lag from graduation to exam writing, and student outcome on the NCLEX-RN.

Participants: A convenience sample of new nursing alumni (2015 graduates) from three universities in an eastern-Canadian province $(\mathrm{N}=117)$ with a response rate of $35 \%$.

Procedure: Following receipt of ethical approval from each university (REB \# 20143336; ROMEO 22448; 1415-203) and the provincial health authority (NSHA-RS/2016-039), graduates were emailed study information and asked to provide their consent for the use of their student data (GPA and HESI Exit Exam and CAT exam scores) for research purposes and to request that, via a password-protected secure email address created for this study, they self-report to a research assistant only their NCLEX-RN Licensure Exam date and result (pass/fail) on their first writing. Student's data sets were completed at each school that included their HESI Exit Exam and CAT scores and GPA, and then the self-reported data of the date of exam writing and NCLEX-RN Exam outcome were added to the data base. GPA calculations are different at each university in this study therefore a common GPA calculation format was used to standardize this variable among all participants. Student identifying data were removed by a research assistant prior to data analysis so that participant anonymity was maintained, as the research team was not aware of which students from which university programs consented to be part of this study. No identifiable data were used throughout the analysis, report writing, and dissemination phases. 


\section{Results}

Data were entered and analyzed using IBM SPSS 22 for Windows. During Phase One analysis, t-tests were conducted to compare HESI RN Exit Exam and CAT scores among those who passed the NCLEX-RN and those who did not pass the NCLEX-RN. HESI RN Exit Exam scores can range from 0 to over 1500, and CAT exam scores can range from 0 to 30. HESI Exit Exam Summary Results are reported with four performance levels: recommended $(>$ or $=$ to 900), acceptable (850-899), below acceptable (750-849), and needs further preparation $(<750)$. HESICAT scores are reported with three result categories: acceptable (16.61-30.00), minimally acceptable (11.51-16.60), and needs further preparation and retesting (0.00-11.50).

Levene's test was used to assess for equality of variances between the groups. Equal variances were reported for the HESI RN Exit Exam Version $1(\mathrm{~F}=.545, \mathrm{p}=.462)$ and the HESI $\mathrm{RN}$ Exit Exam Version $2(\mathrm{~F}=1.264, \mathrm{p}=.263)$. Equal variances for the CAT exam were not found $(\mathrm{F}=6.666, \mathrm{p}=.011)$; therefore, results for the CAT exam are reported as equal variances not assumed.

There was a significant difference in the RN Exit Exam Version 1 scores, $\mathrm{t}(109)=7.62, \mathrm{p}$ $<.0001$ for those who were successful on the NCLEX-RN $(\mathrm{M}=870.20, \mathrm{SD}=135.48)$ versus those who were unsuccessful on the NCLEX-RN (M=669.43, SD=120.97). Students who were successful on their first attempt at writing the NCLEX-RN had a mean score of 870.20 on the first HESI RN Exit Exam, more than a 200 point higher average than those students who were not successful on their first writing. Similarly, there was a significant difference in the RN Exit Exam Version 2 scores, $\mathrm{t}(106)=9.22, \mathrm{p}<.0001$ for those who were successful on the NCLEX-RN $(\mathrm{M}=833.37, \mathrm{SD}=106.73)$ versus those who were unsuccessful on the NCLEX-RN (M=634.86, $\mathrm{SD}=100.21$ ). Students who were successful on their first attempt at writing the NCLEX-RN had a mean score of 833.37 on the second HESI RN Exit Exam, almost a 200-point higher average than those students who were not successful on their first writing.

With the HESI CAT exam scores, significant differences were found $(\mathrm{t}(49)=6.67$, $\mathrm{p}<.0001)$ among those who were successful on the NCLEX-RN $(\mathrm{M}=16.32, \mathrm{SD}=2.30)$ and those who were unsuccessful $(\mathrm{M}=12.13, \mathrm{SD}=3.22)$. Students who were successful on their first attempt at writing the NCLEX-RN had a mean score of 16.32 on the HESI CAT Exam, an over 4.00point higher average than those students who were not successful on their first writing. Table 3 displays the descriptive and t-test findings.

Table 3: Descriptive and t-test results for RN Exit Exam Version 1and Version 2 and CAT scores

\begin{tabular}{|c|c|c|c|c|c|c|}
\hline Exam & $\mathbf{N}$ & Mean & SD & $\mathbf{t}$ & df & $\mathbf{p}$ \\
\hline Exit V1 Pass & 74 & 870.20 & 135.48 & \multirow[t]{2}{*}{7.62} & \multirow[t]{2}{*}{109} & \multirow[t]{2}{*}{.000} \\
\hline Exit V1 Fail & 37 & 669.43 & 120.97 & & & \\
\hline Exit V2 Pass & 73 & 833.37 & 106.73 & \multirow[t]{2}{*}{9.22} & \multirow[t]{2}{*}{106} & \multirow[t]{2}{*}{.000} \\
\hline Exit V2 Fail & 35 & 634.86 & 100.21 & & & \\
\hline CAT Pass & 65 & 16.32 & 2.30 & \multirow[t]{2}{*}{6.67} & \multirow[t]{2}{*}{49} & \multirow[t]{2}{*}{.000} \\
\hline CAT Fail & 33 & 12.13 & 3.22 & & & \\
\hline
\end{tabular}

A backward stepwise logistic regression analysis was conducted to predict the NCLEXRN outcome, with CAT, RN Exit Exam Version 1 and Version 2 scores, GPA, and time lag from 
graduation to exam writing as predictors. The dependent variable, NCLEX-RN outcome, was coded as success (1) and failure (0) with the case processing summary displayed in Table 4. Using the SPSS default cut value of .500, the overall prediction percentage was $86.1 \%$ (Table 5).

Table 4: Case Processing Summary

\begin{tabular}{|c|c|c|c|}
\hline \multicolumn{4}{|c|}{ Case Processing Summary } \\
\hline \multicolumn{2}{|c|}{ Unweighted Cases $^{\mathrm{a}}$} & $\mathrm{N}$ & Percent \\
\hline \multirow[t]{3}{*}{ Selected Cases } & Included in Analysis & 79 & 67.5 \\
\hline & Missing Cases & 38 & 32.5 \\
\hline & Total & 117 & 100.0 \\
\hline \multicolumn{2}{|c|}{ Unselected Cases } & 0 & 0 \\
\hline \multicolumn{2}{|l|}{ Total } & 117 & 100.0 \\
\hline
\end{tabular}

Table 5: Model Classification Table

\begin{tabular}{|c|c|c|c|c|c|}
\hline \multicolumn{6}{|c|}{ Model Classification Table } \\
\hline & \multirow{3}{*}{\multicolumn{2}{|c|}{ Observed }} & \multicolumn{3}{|c|}{ Predicted } \\
\hline & & & \multicolumn{2}{|c|}{ NCLEX } & \multirow[b]{2}{*}{ Percentage Correct } \\
\hline & & & Fail & Pass & \\
\hline \multirow[t]{3}{*}{ Step 1} & \multirow[t]{2}{*}{ NCLEX } & Fail & 18 & 6 & 75.0 \\
\hline & & Pass & 4 & 51 & 92.7 \\
\hline & \multicolumn{2}{|c|}{ Overall Percentage } & & & 87.3 \\
\hline \multirow[t]{3}{*}{ Step 2} & \multirow[t]{2}{*}{ NCLEX } & Fail & 18 & 6 & 75.0 \\
\hline & & Pass & 4 & 51 & 92.7 \\
\hline & \multicolumn{2}{|c|}{ Overall Percentage } & & & 87.3 \\
\hline \multirow[t]{3}{*}{ Step 3} & \multirow[t]{2}{*}{ NCLEX } & Fail & 18 & 6 & 75.0 \\
\hline & & Pass & 4 & 51 & 92.7 \\
\hline & \multicolumn{2}{|c|}{ Overall Percentage } & & & 87.3 \\
\hline \multirow[t]{3}{*}{ Step 4} & \multirow[t]{2}{*}{ NCLEX } & Fail & 18 & 6 & 75.0 \\
\hline & & Pass & 5 & 50 & 90.9 \\
\hline & \multicolumn{2}{|c|}{ Overall Percentage } & & & 86.1 \\
\hline
\end{tabular}

A test of the full model against a constant-only model was statistically significant, indicating that these predictors reliably distinguished between those who were successful verses those who were not successful on the NCLEX-RN (Table 6). Nagelkerke's $\mathrm{R}^{2}$ range of .636 to .669 indicated a moderately strong relationship between prediction and grouping (Table 7). This result suggests that our model as a whole fits significantly better than an empty model with no predictors. The HESI RN Exit Exam Version 2 (Wald=13.10, p<.001) and time lag, defined as the number of days from graduation to NCLEX-RN exam writing (5.461, p value=.019) were significant independent predictors of NCLEX-RN success. There was no relationship between GPA and outcome on the NCLEX-RN (Wald:.502, $\mathrm{df}=1$, $\mathrm{p}$ value=.479). 
Table 6: Variables in the Equation

\begin{tabular}{|c|c|c|c|c|c|c|c|}
\hline \multicolumn{8}{|c|}{ Variables in the Equation } \\
\hline & & B & S.E. & Wald & df & Sig. & $\operatorname{Exp}(B)$ \\
\hline \multirow[t]{6}{*}{ Step $1^{\mathrm{a}}$} & CAT & .185 & .153 & 1.451 & 1 & .228 & 1.203 \\
\hline & Exit V1 & .001 & .004 & .036 & 1 & .849 & 1.001 \\
\hline & Exit V2 & 011 & .005 & 4.360 & 1 & .037 & 1.011 \\
\hline & Time Lag & -.029 & .015 & 3.673 & 1 & .055 & .971 \\
\hline & $\overline{\text { GPA }}$ & .945 & 1.334 & .502 & 1 & .479 & 2.573 \\
\hline & Constant & -12.460 & 4.437 & 7.888 & 1 & .005 & .000 \\
\hline \multirow[t]{5}{*}{ Step $2^{\mathrm{a}}$} & CAT & .196 & .141 & 1.942 & 1 & .163 & 1.217 \\
\hline & Exit V2 & .011 & .005 & 5.684 & 1 & .017 & 1.011 \\
\hline & Time Lag & -.029 & .015 & 3.635 & 1 & .057 & .971 \\
\hline & $\overline{\text { GPA }}$ & 1.050 & 1.219 & 742 & 1 & .389 & 2.856 \\
\hline & Constant & -12.639 & 4.345 & 8.461 & 1 & .004 & .000 \\
\hline \multirow[t]{4}{*}{ Step $3^{\mathrm{a}}$} & CAT & .218 & .140 & 2.428 & 1 & .119 & 1.244 \\
\hline & Exit V2 & .012 & .004 & 8.156 & 1 & .004 & 1.012 \\
\hline & Time Lag & -.032 & .014 & 4.985 & 1 & .026 & .968 \\
\hline & Constant & -10.248 & 3.189 & 10.331 & 1 & .001 & .000 \\
\hline \multirow[t]{3}{*}{ Step $4^{\mathrm{a}}$} & Exit V2 & .015 & .004 & 13.102 & 1 & .000 & 1.015 \\
\hline & Time Lag & -.035 & .015 & 5.461 & 1 & .019 & .965 \\
\hline & Constant & -9.038 & 3.033 & 8.881 & 1 & .003 & .000 \\
\hline
\end{tabular}

Table 7: Model Summary

\begin{tabular}{|l|c|c|c|}
\hline \multicolumn{4}{|c|}{ Model Summary } \\
\hline Step & -2 Log likelihood & Cox \& Snell R Square & Nagelkerke R Square \\
\hline 1 & $46.430^{\mathrm{a}}$ & .473 & .669 \\
\hline 2 & $46.467^{\mathrm{a}}$ & .473 & .668 \\
\hline 3 & $47.206^{\mathrm{a}}$ & .468 & .661 \\
\hline 4 & $49.809^{\mathrm{a}}$ & .450 & .636 \\
\hline \multicolumn{4}{|l|}{ a. Estimation terminated at iteration number 6 because parameter estimates changed by less than .001. } \\
\hline
\end{tabular}

Limitations for this phase of our study included the use of a convenience sample and a small study sample size. Also, we did not collect data related to other learning preparation that students may have used or accessed independently prior to writing the NCLEX-RN; therefore, we are cautious in the interpretation of our findings in that they may not be solely related to the standardized HESI exams that we used within our programs. The advantage within this study is that during Phase Two data collection, we can mitigate this limitation and collect data from new 
nursing graduates related to what, if any, other learning resources were accessed to assist them in preparing for the NCLEX-RN.

\section{Discussion}

Phase One results of this study suggest that there are differences in HESI RN Exit exam and CAT scores among those students who were successful on the NCLEX-RN versus those students who were not successful on the NCLEX-RN at their first attempt at writing. When the average scores of both versions of the HESI RN Exit Exams are combined for those who passed the NCLEX-RN, the resulting mean was 851.79, which indicates that the mean average of all students writing HESI RN Exit Exams was in the minimally acceptable performance range, according to the HESI designated performance levels. The combined mean average of both versions of the HESI RN Exit Exams of those students who were not successful on the NCLEXRN was 652.15, which indicates a performance level of needing more preparation. Furthermore, the HESI CAT exam average of those students who were successful on the NCLEX-RN was 16.32 , which is in the upper range of the minimally acceptable category. Our findings provide support for setting the benchmark of the HESI RN Exit Exam at a score of 850 for optimal student success on the NCLEX-RN.

GPA has been identified as an indicator of success on the NCLEX-RN (Daley, Kirkpatrick, Frazier, Chung, \& Moser, 2003; Dell \& Valine, 1990; Endres, 1997; Higgins, 2005; McGahee, Gramling, \& Reid, 2010; Nibert, Young, \& Adamson, 2002; Seldomridge \& DiBartolo, 2004; Tipton et al., 2008; Waterhouse \& Beeman, 2003). Our findings are contrary to what has been reported in the literature. We are cautious with our findings with this variable given that GPAs were recalculated to ensure a consistent frame of reference values for analysis within this study. However, this finding warrants additional analysis and further discussion for Phase Two of this study. The results of this Phase One study left us wondering why there was no apparent relationship between student GPA and success on the NCLEX-RN.

Lastly, we found an inverse relationship between the length of time from graduation to the date of writing the NCLEX-RN in that the longer the period of time from graduation to exam writing, the less likely it is that the student will be successful. Our findings supported those that were reported by Woo, Wendt, and Liu (2009). These researchers investigated the time lag between NCLEX-RN writing and graduation and similarly reported an inverse relationship. The variable of length of time between graduation and exam writing (time lag) and subsequent success has far reaching implications for those areas in Canada that do not have permanent testing centers that enable students to choose the date that they write their NCLEX-RN. Also, students may be delaying writing the NCLEX-RN exam out of fear of failure on the exam or fear of losing their temporary license to practice nursing.

It is important to note that these results are only the beginning, and we have much more work to do to continue to research student preparatory learning resources for optimal student success on the NCLEX-RN in the Canadian context. We believe that our collaboration and proactive implementation plan for student NCLEX-RN preparation has provided nursing students of this province with beneficial opportunities to prepare for the NCLEX-RN. We believe that our efforts were recently confirmed with the release of Canadian National First Time NCLEX-RN Writer and Ultimate Annual Pass Rates (Canadian Council of Registered Nurse Regulators, 2016) reporting that the province in which the study was conducted had the third highest first-time writer pass rate $(\mathbf{7 5 . 8 \%})$ and the second highest ultimate annual pass rate 
(89.1\%) among the Canadian provinces that use the NCLEX-RN as their entry to practice exam. While we are pleased with our first-year results, comparative to the national landscape, we are cautious to not acquire a sense of security related to our pass rates. We have more work to do to achieve our goal of increasing the success of NCLEX-RN first-time writers pass rates and ultimate annual pass rates. Given our findings that indicated a lack of relationship between a student's GPA and NCLEX-RN success, we are not convinced that the NCLEX-RN is a reliable and valid measure of competence to practice in the Canadian context. Phase Two of this research study will continue to expand our knowledge base for student preparatory learning resources for the NCLEX-RN within the Canadian context to enable us to continue to make evidenceinformed decisions within our nursing programs.

Phase Two data collection will begin in May 2016, when we have our second cohort of students graduating and writing the NCLEX-RN. Research objectives for this phase include repeating Phase One objectives and investigating potential relationships between HESI RN Exit Exam and CAT exam scores, HESI Specialty Exams (nursing fundamentals, pharmacology, maternity, medical-surgical, and pediatrics), attendance at a live three-day face-to-face review session, and NCLEX-RN success.

\section{Conclusion}

The preliminary findings from Phase One of this research study are presented in this article. We found support for the predictive value of the use of the HESI RN Exit Exam and CAT exam within our nursing programs. Furthermore, we have immediate plans to create remediation guidelines for students in the final year of our respective programs, building upon the individualized student reports that are provided by HESI, which are automatically generated from each student's individual performance on the HESI RN Exit Exams. The adoption of remediation policies in nursing programs that include standardized examinations dramatically increases NCLEX-RN first-time pass rates (Serembus, 2016). It may be that the remediation plan is the key learning resource and that the specialized exams are an assessment tool, or proof of concept, for students to prepare for the NCLEX-RN. We are anxious for Phase Two data collection and analysis to begin so that we can continue to build an evidence-informed approach to NCLEX-RN preparation in the Canadian nursing education context to help guide nurse educators to adopt best pedagogical practices in preparing our nursing students for optimal NCLEX-RN success. 


\section{References}

Adamson, C., \& Britt, R. (2009). Repeat testing with the HESI Exit Exam-Sixth validity study. CIN: Computers, Informatics, Nursing, 27(6), 393-397. http://dx.doi.org/10.1097/ncn.0b013e3181bcae08

Barton, L., Willson, P., Langford, R., \& Schreiner, B. (2014). Standardized predictive testing: Practices, policies and outcomes. Administrative Issues Journal, 4(2) 68-76. http://dx.doi.org/10.5929/2014.4.2.2

Canadian Council of Registered Nurse Regulators (CCRNR). (2016). 2015 NCLEX-RN: Canadian results. Retrieved from http://www.ccrnr.ca/nclex---data.html

Daley, L., Kirkpatrick, B., Frazier, S., Chung, M., \& Moser, D. (2003). Predictors of NCLEX$\mathrm{RN}$ success in a baccalaureate nursing program as a foundation for remediation. Journal of Nursing Education, 42(9), 390-398.

Dell, M., \& Valine, W. (1990). Explaining differences in NCLEX-RN scores with certain cognitive and non-cognitive factors for baccalaureate nursing graduates. Journal of Nurse Education, 29(4), 158-162.

Endres, D. (1997). A comparison of predictors of success on NCLEX-RN for African Americans, foreign-born, and white baccalaureate graduates. Journal of Nursing Education, 36(8), 365.

Higgins, B. (2005). Strategies for lowering attrition rates and raising NCLEX-RN pass rates. Journal of Nursing Education, 44(12), 541-547.

Homard, C. (2013). Impact of a standardized test package on exit examination scores and NCLEX-RN outcomes. Journal of Nursing Education, 52(3), 175-178. doi:/10.3928/01484834-201302-01

Hyland, J. R. (2012). Building on the evidence: Interventions promoting NCLEX success. Open Journal of Nursing, 2(3), 231-238. http://dx.doi.org/10.4236/ojn.2012.23036

Langford, R., \& Young, A. (2013). Predicting NCLEX-RN success with the HESI exit exam: Eighth validity study. Journal of Professional Nursing, 29(2), S5-S9. http://dx.doi.org/10.1016/j.profnurs.2012.06.007

Lauer, M. E., \& Yoho, M. J. (2013). HESI exams: Consequences and remediation. Journal of Professional Nursing, 29(2), S22-S27. http://dx.doi.org/10.1016/j.profnurs.2013.01.001

Lauchner, K., Newman, M., \& Britt, R. (1999). Predicting licensure success with a computerized comprehensive nursing exam: The HESI Exit Exam. CIN: Computers in Nursing, 17(3), 120-128. http://dx.doi.org/10.1097/00024665-200605001-00002

Lewis, C. C. (2005). Predictive accuracy of the HESI exit exam on NCLEX-RN pass rates and effects of progression policies on nursing student exam scores [Abstract]. Southern Online Journal of Nursing Research, 8(2). Retrieved from http://www.resourcenter.net/images/snrs/files/sojnr_articles2/Vol08Num02L.html\#Lewis $\mathrm{C}$ 
McGahee, T., Gramling, L., \& Reid, T. (2010). NCLEX-RN success: Are there predictors? Southern Online Journal of Nursing Research, 20(4). Retrieved from http://www.resourcenter.net/images/snrs/files/sojnr_articles2/Vol10Num04Art13.html

Newman, M., Britt, R., \& Lauchner, K. (2000). Predictive accuracy of the HESI Exit Exam: A follow-up study. CIN: Computers in Nursing, 18(3), 132-136.

Nibert, A., \& Morrison, S. (2013). HESI testing-A history of evidence-based research. Journal of Professional Nursing, 29(2), S2-S4. http://dx.doi.org/10.1016/j.profnurs.2012.06.004

Nibert, A., \& Young, A. (2001). A third study on predicting NCLEX success with the HESI Exit Exam. CIN: Computers in Nursing, 19(4), 172-178.

Nibert, A., Young, A., \& Adamson, C. (2002). Predicting NCLEX success with the HESI Exit Exam: Fourth annual validity study. CIN: Computers in Nursing, 20(6), 261-267. http://dx.doi.org/10.1097/00024665-200211000-00013

Seldomridge, L., \& DiBartolo, M. (2004). Can success and failure be predicted for baccalaureate graduates on the computerized NCLEX-RN? Journal of Professional Nursing, 20(6), 361-368. http://dx.doi.org/10.1016/j.profnurs.2004.08.005

Serembus, J. F. (2016). Improving NCLEC first-time pass rates: A comprehensive program approach. Journal of Nursing Regulation, 6(4), 38-44. http://dx.doi.org/10.1016/s21558256(16)31002-x

Sugg, J. (2015). Nurse educators' perspectives of supplemental computer-assisted formative assessment in an associate degree nursing program. (Doctoral dissertation). Walden Dissertations and Doctoral Studies. Retrieved from http://scholarworks. waldenu.edu/cgi/viewcontent.cgi $?$ article $=1605 \&$ context=dissertations

Tipton, P., Pulliam, M., Bechworth, C., Illich, P., Griffin, R., \& Tibbitt, A. (2008). Predictors of associate degree nursing students success. Southern Online Journal of Nursing Research, $8(1)$. Retrieved from http://www.resourcenter.net/images/snrs/files/sojnr_articles2/vol08num01art02.html

Waterhouse, J., \& Beeman, P. (2003). Predicting NCLEX-RN success: Can it be simplified? Nursing Education Perspective, 24(1), 35-39.

Woo, A., Wendt, A., \& Liu, W. (2009). NCLEX-RN pass rates: An investigation into the effect of lag time and retake attempts. JONA's Healthcare Law, Ethics \& Regulation, 11, 2326. http://dx.doi.org/10.1097/nhl.0b013e31819a78ce

Young, A., \& Willson, P. (2012). Predicting NCLEX-RN success: The seventh validity study HESI Exit Exam. CIN: Computers, Informatics, Nursing, 30(1), 55-60. doi:10.1097/NCN.0b013e3182343edf

Zweighaft, E. L. (2013). Impact of HESI specialty exams: The ninth HESI exit exam validity study. Journal of Professional Nursing, 29(2), S10-S16. http://dx.doi.org/10.1016/j.profnurs.2012.06.011

Zweighaft, E. L. (2014, March). HESI exams and student success. Oral presentation at Elevate Outcomes with HESI- Contemporary Forums, Las Vegas, NV. 